\title{
The rise of authoritarianism in a democratic regime in Aristophanes' Assemblywomen ${ }^{1}$
}

Greice Drumond ${ }^{2}$

\begin{abstract}
The plot of Assemblywomen tells the story of a coup organized by a group of women to conquer power and administrate the city of Athens. By examining the historical and dramatic elements in this comedy, we seek to comprehend the use of the notions of liberty and democracy, taking into consideration that through the drama we glimpse on what can happen when democracy is undermined. Aristophanes made use of artistic liberty to redefine the parameters of his art, showing a new form of comedy and how liberty can contribute to the development of art and society.

Keywords: Athenian democracy; Aristophanic comedy; Assemblywomen; liberty; coup.
\end{abstract}

Resumo: A trama de Assembleia de Mulheres conta a história de um golpe organizado por um grupo de mulheres para conquistar o poder e administrar a cidade de Atenas. Ao examinar os elementos históricos e dramáticos desta comédia, buscamos compreender o uso das noções de liberdade e democracia, levando em consideração que, nesse drama cômico, entrevemos o que pode acontecer, quando a democracia se encontra enfraquecida. Além desse aspecto narrativo, Aristófanes fez uso da liberdade artística para redefinir os parâmetros de sua arte, apontando um novo formato de comédia e mostrando como a liberdade pode contribuir para o desenvolvimento da arte e da sociedade.

Palavras-chave: democracia ateniense; comédia aristofânica; Assembleia de Mulheres; liberdade; golpe.

\section{Introduction}

The play Assemblywomen (Ecclesiazousai) ${ }^{3}$ presents us with an opening scene of women preparing themselves to attend the essential democratic institution of Athens's governing

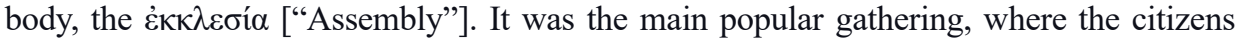
could vote on decrees that ruled many political aspects of Athenian life. In the Assembly, the citizens could speak out their minds and try to convince one another in policy issues.

1 I want to thank Dr. Herbert Bannert (Vienna, Uni Wien) and Fernando Brandão (Araraquara, UNESP) for encouragement and advices (some of which I have followed). A special thanks to my husband Thomas, for the review of the English text. Some of the considerations here presented were developed on a previous paper, Lei e Liberdade em Assembleia de Mulheres de Aristófanes (2014) ["Law and Liberty in Aristophanes' Assemblywomen"].

2 Professor at Universidade Federal Fluminense (UFF). Researches translation of Ancient Greek comedies.

3 The abbreviation of the play will follow the denomination Ecclesiazousai (Ecc.) as a standard reference to Assemblywomen. 
At the time of the performance of this play, Athens deals with the current contradictions of the beginning of the fourth century $\mathrm{BC},{ }^{4}$ since this city has lived its peak in the fifth century $\mathrm{BC}$ and is now trying to rise after all the wear caused by the prolonged war against Sparta (431-404 BC) while passing through another military confrontation, the Corinthian War (395-387 BC).

At the end of the Peloponnesian War in 404 BC, Athens was briefly under the Thirty Tyrants, an oligarchic government instituted with the support of Sparta and elected by the Athenians. During this time, prominent citizens considered hostile to the government were exiled, sentenced to death, or had their property confiscated. Shortly after this experience of being under control of the tyrants, Athens is allowed to restore its democracy. For this, several legal changes have been made so that now the democratic government would become more efficient.

A review of the Athenian constitution was undertaken meanwhile. ${ }^{5}$ It resulted in a clear distinction between the concept of permanent essence of the laws (vó $\mu \circ$ ) and the temporary nature of decrees ( $\psi \eta \varphi i ́ \sigma \mu \alpha \tau \alpha)$. After 403 BC, the Athenian Assembly was in charge of creating decrees only, losing the power of proposing laws it had before. ${ }^{6}$

Aristophanes criticized the participation of citizens in the Assembly in exchange for monetary compensation of three obols, as we can see in the references in Assemblywomen (291-292, 380-381). ${ }^{7}$ The reintroduction of this payment can be one of the reasons why Aristophanes has chosen the popular Assembly as a topic plot, pointing out that people were attending it for their own interest and not for the common welfare. ${ }^{8}$

The heroine Praxagora draws up a plan to abolish all private property, obliging citizens to deliver their goods to the city administration so that they can be equitably redistributed with the aim to eliminate socioeconomic differences. For this, she comes to meet her friends in order to prepare their participation in the Assembly, so they can be ready to vote on the proposition of the heroine to hand over the power to women. They are preparing a coup using democratic means; thus, the comedy mocks democracy's weakness.

The argumentation in the plot is that, since women know how to manage the household, they could as well permanently manage the polis. The project is entirely absurd if we consider that a woman would never be allowed to play that role in Athenian society since their participation in the Assembly was forbidden. Nevertheless, on the other hand, why could not the way of handling the oikos, the private sphere, be employed in the man-

4 The exact year of the first production of this play is not known. However, it can be inferred by the internal references (implicit didascalia) that Assemblywomen could have been staged before the death of Thrasybulus (389 BC), since Praxagora, heroine of the piece, mentions him in line 203. The year 392 BC is most commonly agreed by scholars.

5 During 403-399 BC, as pointed out by Hansen (1978, p. 29).

6 See ROTHWELL, 1990, p. 15; LEWIS, David M., 1994, p. 24-44.

7 The criticism of a payment offered to the citizens so that they could participate in the Assembly is also made in Knights (51). This action had been instituted in the period of Pericles, as a form of compensating especially those who had left their work to attend meetings, thus making their civic duties viable. In $411 \mathrm{BC}$, this payment was suspended. It was reintroduced at the beginning of the $4^{\text {th }}$ century when it was realized that people were not attending the Assembly (see ARISTOTLE, Athenian Constitution, 41.3). So, in Assemblywomen, Aristophanes deals with the return of this payment at the beginning of the $4^{\text {th }}$ century $\mathrm{BC}$, and his criticism is due to an increase of this ammount from one to three obols a short time before Ecclesiazousai came out (Ecc., 302).

8 Aristotle refers to this payment made to the poor ones to attend the Assembly as a characteristic of democracy (Politics, 1294a30-1294b1). 
agement of public affairs as it works so well? If the citizens try their best for their own houses, why could the polis not be organized with the same care? Moreover, who would be better qualified than the manager of the oikos, i.e., the women?

We can also see the vital role of women in the administration of the oikos in Oeconomics by Xenophon. In this dialogue, Ischomacus claims that he does not need to stay home, because his wife was more than enough to take care of the house (XENOPHON, Oec., 7.3). She is considered to be the guardian of the laws in the house, as

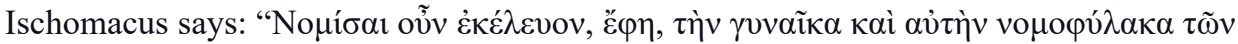

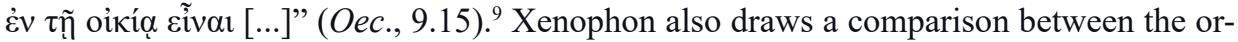
ganization of the house and the city (Oec., 8.11-22).

Nonetheless, we must consider that on the plot of Assemblywomen, the female characters only achieved victory by speaking, acting, and disguising themselves as men. They could, therefore, vote to deliver the city administration to themselves. Here we see the comical game made with a reverse situation. This also happens in Lysistrata, where women make a sex strike and temporarily occupy the Acropolis to force men to give up the fratricidal war. To put women in the scene is also a way of getting the attention of the audience, to make people think about what the government of Athens, composed entirely of men, has done so far and to reflect on how political choices affect the society.

Undoubtedly, fantasy and irony are juxtaposed in this piece, according to the words of Zumbrunnen (2012, p. 108), because, on the one hand, there was no possibility of a government established by women; on the other hand, the proposal to end the division of citizens into different economic groups was far from being something tangible only through the imposition of a decree or law, as the play ironically shows us. We also understand that this can sound like criticism against the confiscation of the property of the wealthy citizens, as we can see in Aristotle (Pol., 1305a), because actions like this can lead the government of the city into a tyrannical form.

Concerning the women's procedure on the play, Magnelli (2017, p. 409) prefers to call it a "political revolution". Dover (1972, p. 191) denominates it "political reforms". We give it a name - coup - because they got the power through manipulation, and one cannot grant that their campaign commitments were satisfactorily fulfilled. By occupying most of the seats of the Assembly disguised as men, they got to establish the coup.

\section{Preparing the coup}

As already mentioned, the opening of the play introduces a meeting of a group of women. They carry out a dress rehearsal to get prepared to participate jointly in the Assembly wearing men's clothing. They then brought forward their plan at the Assembly and voted in favor of their proposal as if they were men, nominating Praxagora to be the leader, as we can see:

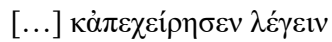

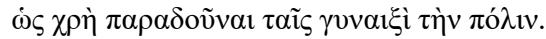

9 "So I charged my wife to consider herself guardian of the laws to our household." The translations of Xenophon's Oeconomicus are made by Marchant (1997). 


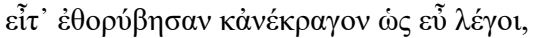

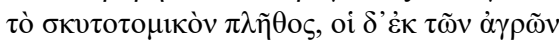

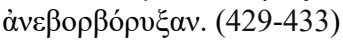

He [Praxagora] made the case for handing the city over to the women. And they all cheered and yelled 'well said,' this mass of cobblers, while the people from the country made deep rumbles. ${ }^{10}$

The transvestism is featured with beards, canes, shoes, and cloaks the women were wearing. Nonetheless, they still stirred up a bit of unease in the men who were attending the meeting because they had the look of men who work in enclosed spaces, as Chremes

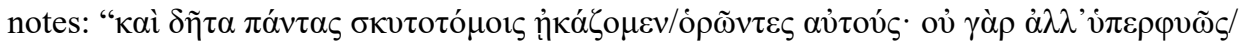
$\dot{\omega} \varsigma \lambda \varepsilon v \kappa о \pi \lambda \eta \theta \dot{\eta} \varsigma \tilde{\eta} \nu$ i $\delta \varepsilon \tilde{\imath} \nu \dot{\eta} \kappa \kappa \lambda \eta \sigma i ́ \alpha " 11$ (385-387). Praxagora herself is recognized as a good-looking guy, maybe a little bit feminine according to Chremes' description: " $\mu \varepsilon \tau \grave{\alpha}$

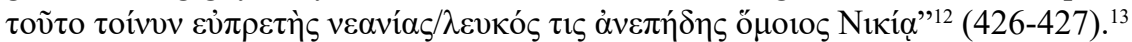

Such awkwardness shows the apparent grotesque aspect of these characters. These women were characterized by a mixture of masculinity, thanks to clothing and speech, and femininity due to their skin color. This passage is funny, for the hilarious dialogue about what could have been seen at the Assembly. We also must consider that the women's outfit causes the cross-dressing of their husbands too: their clothes have disappeared, and they were forced to wear their wife's garments while the women were attending the Assembly - either this or stay naked (Ecc., 373-374). This exchange of clothes can also indicate a turnaround of roles: it is up to men to stay at home while women can take a seat in the Assembly. The reversal of power was thereby accomplished.

Since the majority of the Assembly was composed of women pretending to be men, the few males attending the meeting either felt forced to agree or had to accept the result of the election, as the farmers did (Ecc., 432-433). It resembles what happened for the election of the Thirty Tyrants when many of the exiled citizens that had returned were aiming for an oligarchic regime and participated on the election, having a significant or even coercive influence on the other members of the Assembly, as Aristotle (Ath. Pol., 34.3) ${ }^{14} \mathrm{de}-$

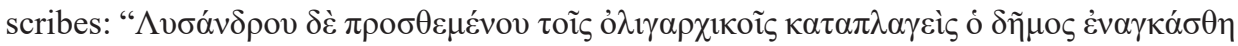

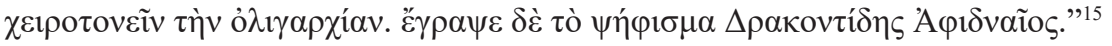

10 All the translations of Aristophanes' Assemblywomen are taken from the Loeb edition of Jeffrey Henderson (2002). As we can see in this excerpt, the ones who work with agriculture were not happy with the result of the voting process.

11 "And you know, we thought they all looked like shoemakers; really, the Assembly was awfully pale faced to behold."

12 "Well, after that pale, good-looking young man sprang to his feet to address the people; he looked like Nicias."

13 Nicias was an Athenian politician and a general. After Pericles death in 429 BC, he became the chief opponent of Cleon, who was a promoter of the Peloponnesian War. "His policy was to encourage a moderate attitude towards Sparta and to discourage the extreme imperialism of the democrats", according to John Hazel (2002, p. 165). He is mocked by Aristophanes since Knights (424 BC).

14 Ath. Pol. is the standard abbreviation for the Athenian Constitution. It comes from 'A $\theta \eta v \alpha 1 \tilde{\omega} v$ Пo $\lambda \iota \tau \varepsilon i ́ \alpha$ (Athenaion Politeía). All the translations of Aristotle's Athenian Constitution were made by Rackham (1981) from the Loeb edition.

15 "And when Lysander sided with the oligarchical party, the people were cowed and were forced to vote for the oligarchy. The motion was proposed by Dracontides of Aphidna." Note that the word translated as "motion" is " $\psi \eta \dot{\eta} \varphi \imath \mu \alpha "[$ "decree"]. This oligarchic regime lasts only a few months in power. 
Apart from abolishing the traditional assignment of labor and chores according to the gender, the women's plan also includes a redistribution of goods. This seems to echo some ideas that are found in Plato's Republic, as it regards that guardian duties should be assigned to men and women alike and that the assignment of specific tasks should be made under personal aptitude, not defined by gender (Rep., 451d-457c). The guardians should own no private property (Rep.,417b ff.) since everything is shared in the community. Women would be a common good to all guardians, and their children would be raised in a community home (Rep., 457d), precisely as Praxagora proposed (613-614, 634-635).

Because the play chronologically precedes the philosophical dialogue, it is possible that Plato was influenced by the plot or that both authors have been taking the idea from the same source. ${ }^{16}$ For sure, as in other Aristophanic comedies, this plot is a way for the author to critique the state of affairs of his time. Men were mismanaging the polis, so he proposes the absurdity of accepting a government composed of women, at least in the plot. The argument used was that such an idea of having women in power was the only thing that had not been tried so far in favor of the city (Ecc., 455-457).

On the other side, in the early $4^{\text {th }}$ century $\mathrm{BC}$, revolutions, as highlighted by Aristotle in Politics, took place in some democratic states. He claims that, in democracies, the principal cause of revolutions is the insolence of the demagogues; for they cause the owners of property to band together, partly to malicious prosecutions, and partly by setting on the common people against them as a class (ARISTOTLE, Pol., 1304b ff.). That is what took place, recently, during the regime of the Thirty Tyrants: elected by the Athenian citizens, they prosecuted some of the wealthy members of their society, seizing their properties afterward, as we can see in Aristotle's description in Athenian Constitution (35.3-4), when he explains that, in the beginning, the oligarchic government was engaged in matters that pleased the population, removing the blackmailers and the persons who consorted unde-

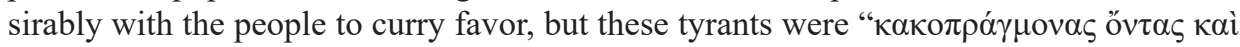

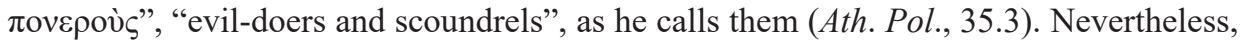
the state was delighted at these measures, thinking that they were acting with the best intentions. However, when they got a firmer hold on the state, they put to death those of outstanding wealth, birth, or reputation, continues the philosopher. ${ }^{17}$ How can we not call the action of the women at the Assembly a coup, though they have reached power through democratic forms, not using physical violence in their rise?

In the play, the contrast between poverty and wealth is exposed to show the existence of individuals who are living in abundance, despite those who have very little to survive. For instance, one of Praxagora's companions complains that her son has nothing to wear (92). The heroine's speech addresses this complaint, aiming to establish the redistribution of goods. She points out the division of the citizens into two groups:

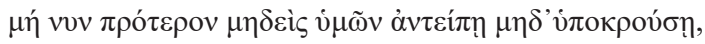

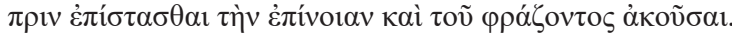

16 See HENDERSON, 2002, p. 242.

17 ARISTOTLE, Ath. Pol., 35.4 . 


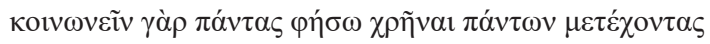

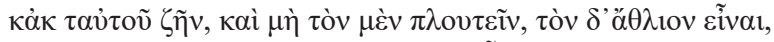

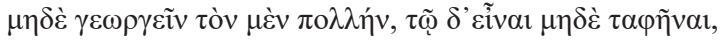

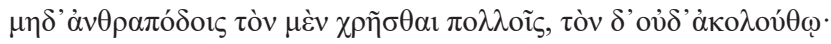
à $\lambda \lambda^{\prime}$ '

Then let one object or interrupt until you've heard the speaker out and understand the plan. Very well: I propose that everyone should own everything in common, and draw an equal living. No more rich man here, poor man there, or a man with a big farm and a man without land enough for his own grave, or a man with many slaves and a man without even an attendant. No, I will establish one and the same standard of life for everyone.

This is how the idea of redistributing goods is announced and lightly debated. The agon $^{18}$ of the Assemblywomen (571-710) consists of a simple display of a gynarchic government plan, without strong opposition, since heroine's project had already been previously voted at the meeting. Now only some outstanding details about the new world inaugurated by the heroine are questioned. The inquiries of Blepyrus and his neighbor aim to clear up the details of the redistribution, not only of the goods but also of food and sexual pleasures. Already as early as in the agon, we begin to assume the consequences of carrying out the leader's intent, but then the comedy writer will surprise us with an unexpected twist. Some aspects of the effects of Praxagora's plan concerning the dynamic and sometimes frictional relation between the city rules and the citizens' freedom are further presented in our analysis of two episodes of the play.

\section{Artistic innovation}

The first episodic section (711-729) of Assemblywomen serves as a transition to the second part of the play (729-1183), on which the protagonist should be performing on stage. However, differently to previous comedies where the heroes lead the development of the action from the beginning to the end, this is the last apparent participation of the heroine on stage. She leaves the scene in the middle of the play in order to go to another offstage place to carry out the function she got designated at the meeting on which the properties of the citizens are being received to a further redistribution. From then on, she will no longer actually perform on the drama. Removing the main character of the scene is uncommon, at least in the surviving comedy plays. ${ }^{19}$

In this excerpt, Praxagora repeats the parameters of her plan as exposed in the agon. It is only in the next two episodes that we have the second part of the play, where, usually, the consequences of the execution of the comic hero's plan are exposed.

18 The structure of Aristophanic comedies can grosso modo be divided into two blocks. Initially, the hero's plan is exposed in the prologue and debated on the agon. The second block of the comedy play shows the consequences of the achievement of the hero's plan, especially through the episodes.

19 Nevertheless, in the Greek epic poems, it was not uncommon to make the hero disappear for a time, just like Achilleus, that leaves the scene at the beginning of the Iliad and makes a punctual appearance in the Book IX, returning to the war only on the XVI, and Odysseus, which journey is narrated from the Book IV of the Odyssey. 
What we find after this section is the so-called XOPOY mark, which can be translated as "part of the chorus". Following the argumentation of Rothwell (1995, p. 111), this choral mark indicates a performance of the chorus not directly related to the plot, possibly being an embolimon that serves to switch distinct episodes of the play, making a transition between the parts with a performance of the choir unlinked to the what is being played. ${ }^{20}$ This is something completely new in a surviving Aristophanic play. Without the intervention of the chorus in the episodes, the drama is more centered on the dialogue,${ }^{21}$ creating an environment in which the individual voice dominates in the plot, as we can further see on Menander's plays.

The absence of the chorus lyrics is an innovation appointed on fragment 21.14 Koster, ${ }^{22}$ relating to Wealth, the last surviving play of Aristophanes, on which this same XOPOY mark indicates a choral performance disconnected from the plot, just as in $A s-$ semblywomen. This testimonium asserts that Wealth, being deprived of a choir, would have influenced the structure comic genre in the later stage.

With the departure of Praxagora, it is up to other characters to drive forward the action of the play. In the second episode (730-876), the scene is in the hands of two characters that are not even lexicalized, i.e., their names are not even mentioned. ${ }^{23}$

\section{The consequences of the coup}

In this section, two individuals happened to meet one another. One of them resolutely refuses to deliver his goods, claiming that they were obtained with hard work (746-754). The other one submits without questioning. ${ }^{24}$ The first character, seeing the submission of his neighbor by carrying his belongings out of the house, tries to figure out what is happening. In a walk through the city, he was apprised about the new situation.

Although everything had been decided at the Assembly, the rebellious character in this episode refuses to accept the new reality, making objections to the heroine's plan. Precisely because it was something enacted by the members of the Assembly, the opponent mentions a couple of resolutions taken by the citizens, which had a negative effect on their lives. He considers delivering his goods to the city administration as a sign of stupidity, of a "voṽv ó $\lambda$ ífov", a "short mind person" (747). He says that sometimes what is decided at the Assembly can harm ordinary people, as can be seen in the examples given by that character referring to the decree on salt production and the resolution concerning the copper coinage $(812-822) .^{25}$

20 Aristotle refers to the composition embolima for Euripides and Agathon in Poetics (1456a29), described as a choral interlude not connected to the plot's issue. It conduced to the further division of the play in acts. See ROTHWELL, 1995, p. 111.

21 This is one conclusion attested by Kibuuka (2010, p. 141).

22 HENDERSON, 2007, p. 78.

23 In fact, there are discussions about the identity of one of the characters in this episode. There is the interpretation that one of them is Blepyrus' neighbor, Chremes, which appeared in the first part of the piece and returned (see MÖLLENDORF, 2002, p. 117). The other opinion is that this man is the neighbor present on the first episodic scene (see SOMMERSTEIN, 1998, p. 203).

24 Apparently, the one who obeys the recent rules was with Blepyrus during the agon when Praxagora's plan was elucidated.

25 There is no historical evidence of a case about salt. Concerning the copper coinage, this had already been 
Praxagora's argument has won in the agon, but her plan is not unanimously accepted. In the second part of the play, in the episodes, Aristophanes starts to describe the individual reactions, showing how a person can behave when faced with the idea of public welfare and its costs. Or can it be that he is approaching the subject of the imposition of the law?

The character called "Selfish" by Henderson (2002) believes that he must be convinced by facts rather than arguments. For him seeing before believing is mandatory when he says that he will only obey when he sees other people delivering their properties (771). He claims that once men voted quickly for something, it can happen that when it comes to the execution, they refuse to comply with the laws, even under the threat of punishment (797-798). In his opinion, it is better to wait and see what happens before handing over his property to the government. We cannot forget what has happened in the recent past with the Thirty Tyrants' government: part of the citizens, thinking that they would be favored, got betrayed by them.

When the neighbor of Blepyrus decides to deliver his goods, ${ }^{26}$ his justification is that

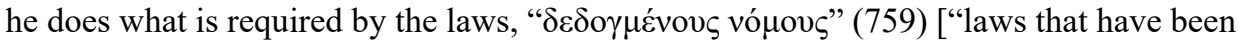
enacted"]. In fact, in the agon, he was persuaded by Praxagora to agree with her plan, even though he had not voted for it. Thus, what is ironically being represented here is the consequence of the non-participation of both persons in the Assembly: one because he could not attend the meeting due to outfit issues, since his wife took his clothes, and the other because he did not exercise his right to vote.

In this scene, we can observe the use of the term vó $\mu$ o [ ["law"] considered as something that was $\delta \varepsilon \delta$ ó $\gamma \mu \varepsilon v o v$ ["decreed", "enacted", "voted"] in the Assembly:

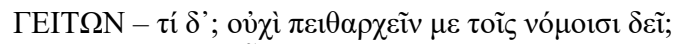

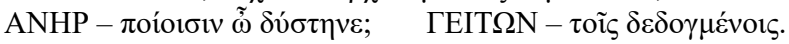

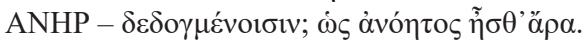

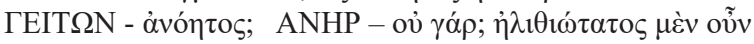

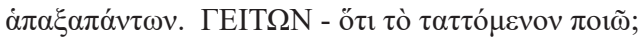

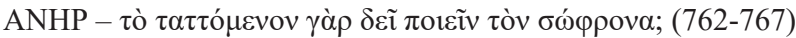

NEIGHBOR - Really? I'm not supposed to obey the laws?

SELFISH MAN - What laws, you sadsack? NEIGHBOR - The laws that have been duly [enacted.

SELFISH MAN- Duly enacted! How stupid can you get?

NEIGHBOR - Stupid? SELFISH MAN - Well, aren't you? And not just stupid, but the biggest simpleton in the world? NEIGHBOR - Because I do what I'm told?

SELFISH MAN - So you think the man of sense ought to do what he's told?

Rothwell (1990, p. 15) says that it became more difficult to alter laws after 403 BC due to the revision of the constitution. As stated at the beginning of this paper, the Athenians deepened the distinction between vó $\mu$ ऽ ["law"], considered permanent, and $\psi \eta \dot{\varphi} \varphi \iota \mu \alpha$ ["decree"], which is seen as ephemeral. So, if one seeks for a change in the laws of the

cited in Frogs (725-726). Athens began to mint copper coins in 406 BC, so that the gold of the city could be used for the fabrication of the Nike statue in the Parthenon. This depreciated the newly used currency (see SOMMERSTEIN, 1998, p. 209).

26 This character is called "Neighbor" in the Henderson's translation of this play. 
city, this task could only be made by a special jury, formed by vo $\mu \circ \theta \varepsilon ́ \tau \alpha 1$ ["legislators"], ${ }^{27}$ and not by the members of the Assembly. Consequently, it had reduced the importance of the Assembly, contributing to a more significant lack of interest of the citizens in this space of political action.

On the other side, it is interesting to highlight here the thought of Aristotle (Pol., 1292a2-7), concerning the concept of law and decree, when he claims that demagogues make the decrees of the Assembly override the law and that in states under the democratic government guided by law, and not by decree, a demagogue does not arise. ${ }^{28}$ Let us not forget that Praxagora proposal was made in the Assembly, imposing thus a decree as the sovereign rule, just as the Thirty Tyrants did. ${ }^{29}$

Aristophanes, as $\delta 1 \delta \alpha ́ \sigma \kappa \alpha \lambda \circ \varsigma$ ["teacher", "master"], ${ }^{30}$ shows his audience a plot related, as he usually does, to current facts at his time, pointing to a need of a change in the mindset of the citizens regarding their participation in the deliberations of the city - not only to what concerns the welfare of the society, as Praxagora ideally express (Ecc., 594), but also to make the spectators think of being more careful about the decisions taken in the Assembly, as the selfish character points out so well in the second episode (Ecc., 730-876).

After all, being permanent or not, the decrees arranged the way how individuals should coexist. By any means, the characters refer to the decisions of the Assembly as

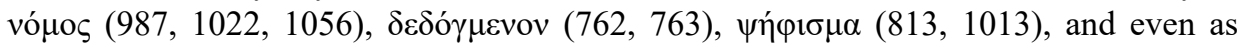

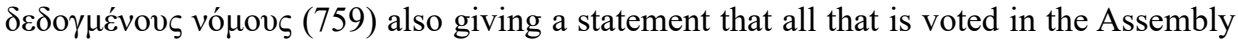
is important since it was decided by its members, who represent the will of the people, at least in theory. It does not matter if what is voted is called law or decree. The characters do not distinguish the use of these words. ${ }^{31}$

\section{Questioning the effectiveness of the new government's program}

Aristophanic plays usually present us a hero/heroine with freedom to question the situation in which he/she lives, whether in the economic, social, cultural, or political area. In Assemblywomen, we have a secondary character who criticizes the plan of the heroine with an argumentation based on examples showing that the decisions enacted in the Assembly can be questioned. Even depicted as selfish or rebellious, this character is also representing the freedom of thought that the individual may have towards what is being (im)posed to him.

27 See DEMOSTHENES, Against Timocrates, 24.27.

28 Aristotle's political thought will not be discussed here. However, we note that in this excerpt of Politics, he emphasizes the idea of more participation of the agricultural population, instead of the massive presence of the impoverished urban Athenians (see MORRALL, 1977, p. 94-98).

29 It is interesting to check what is written in Andocides' speech On the Mysteries 87, where a distinction be-

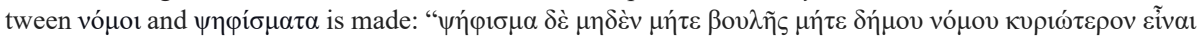
["No decree, whether of the Council or Assembly, shall override a law "] (transl. by K. J. Maidment).

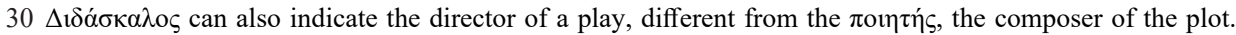
Aristophanes, in this play, is both.

31 Hansen (1978, p. 36) collected eleven instances from the period of 403-322 BC, a few, indeed, on what $\psi \eta \varphi i ́ \sigma \mu \alpha \tau \alpha$ could be considered as "general permanent rules enacted by the ecclesia in the form of a psephisma and not by the nomothetai as a nomos." It can show us that the characters consider this decree as a permanent rule. 
Despite being out of the play's action, we note that Praxagora keeps pulling strings in the next two episodes. Actually, the naïve character is an extension of the heroine to carry out her plan, thus taking himself her place. He assumes the role of the protagonist, driving the action, and even being able to suffer strong opposition from his interlocutor, which only fits a character of heroic dimensions, at least in ancient Greek comedy. ${ }^{32}$

Nevertheless, why did Aristophanes place such a strong opponent in the scene? He seems to play with the heroine's proposal to show that social order issues should have nothing to do with individual interests. If we remember that, in Acharnians, the comedy writer opposed the Greeks' enthusiasm for war, represented by the secondary characters on the play, to the desire of peace of the hero, we can understand that the author makes the audience think about the position they can take when facing different sides of the question. For Saïd (1996, p. 301), this play puts the finger on the sore of the selfish behavior of the Athenians by attacking it, since the citizens are interested in the Assembly, presumably due to personal financial benefits.

The plot points out that they vote solely on what brings them personal and immediate gain. The problem is also concerned with the danger of a demagogue rising in this scenario, making promises of sharing the wealth among people to hide suspicious ambitions on collecting all the properties of the citizens. We also consider that this opposition represents the resistance of the individuals with some property that live in a city whose majority do not have even a "middle-class" status, as Aristotle imagined for a composition of an ideal city in Politics (1295b25-30). Praxagora statement is that she will establish one

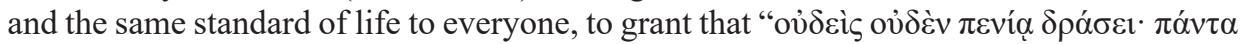

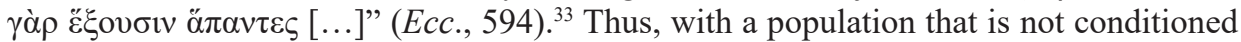
by poverty in the conduction of the interest of the city would strengthen democracy.

In addition, what can also be highlighted is that this "selfish" character plays the role of a counterpart since the citizens can be guided by demagogical leaders, being convinced, at the moment, that some choices are advantages, but realizing later what kind of a trick it was, in conformity to what we can read on the lines 812-822, when he takes into account that some decisions made by the population in the Assembly hindered the society.

In this second episode, the new government implements one point of the program previously announced by the leader: the collection of goods for further redistribution, followed by community meal that the leader offers to all citizens. The first part of the plan is thus half-fulfilled by showing only the collection of the citizens' properties without redistributing it. This excerpt ends by using the XOPOY mark for the second time, after line 876, which indicates the choir's unrecorded participation.

\section{Love is in the air}

The third and final episode (877-1111) puts new characters on stage: three crones and a couple in love. As far as we know, this moment of the play is the first "romantic" scene ever performed in a surviving Aristophanic comedy. ${ }^{34}$

32 We can also think the play's leading role has also undergone the new law of sharing everything since the main character's part is also exchanged among the secondary ones.

33 "No one will be doing anything as a result of poverty, because everyone will have all the necessities [...] (emphasis in italics is given by the translator).

34 There is a scene with Myrrhina and Kinesias in Lysistrata (845-979) in which the wife actually avoids her 
In this part of the play, the implementation of another point of the heroine's project takes place: equal opportunities of sex for everyone. From now, the young and beautiful shall no longer have the privilege of succeeding in the pursuit of sexual pleasures. The old and ugly instead get priority. Since they usually are unable to win in the art of seduction against the young people, they should first be satisfied before any other person engages in a sexual encounter.

This part is structured in a scene that is performed with song, music, and sensuality. The first character to appear is a crone, with heavy makeup and dressed to kill:

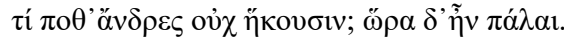

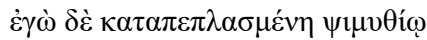

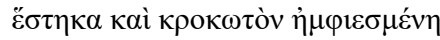

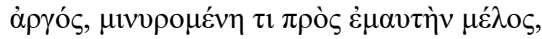

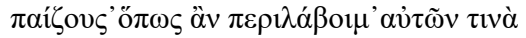

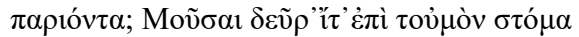

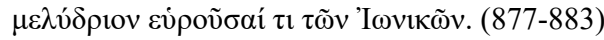

What can be keeping the men? They're long overdue. Here I am, all plastered with makeup and wearing a party dress, just standing around, whistling myself a song, and my trap all set to snag one of them as he passes. Ye Muses, come sit on my lips, and find me some spicy Ionian tune. ${ }^{35}$

This first image already shows us the contents of this last episode: instead of goods, the discussion here deals with the issue of the common right of getting equal access to sex. The crone is rivaling a young girl and will have to fight to attract the attention of a young man, Epigenes, in order to accomplish her intent with him.

As in the previous episode, the plot shows us an individual who does not adjust himself to the new state of affairs. Just like the selfish character that does not want to hand over his property to the state, Epigenes does not want to surrender to the ugly crone. Instead, he wants to meet his young lover. And once more, we note that the heroine's action does not rely on the general willingness to cooperate.

The crone will be the first one to defend Praxagora's plan, playing the role of the main character in this first moment of the episode. Her young contender appears soon after line 884 , daring to rival the crone by singing in response to the elderly lady's song on her attempt to seduce someone. The battle gets started, therefore, even before the arrival of the young man, reason for further dispute. Aristophanes' boldness in putting two characters in a musical contest highlights his skill as a lyrical composer, always being on the nerve of his time. One of the reasons can also be the change in the musical taste of the public

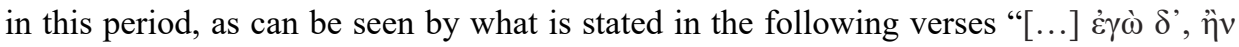

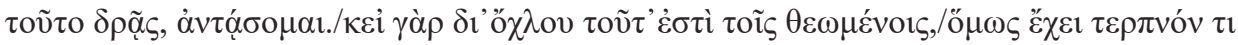

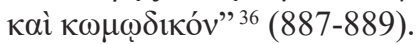

husband, teasing him sexually, and promising to give in only when peace is voted. It was part of the heroine's plan to use sex for bargaining. However, using sex as currency in a deal cannot be compared with the compassion of two lovers displayed here.

35 Ionian music means music with sexual connotation (see SOMMERSTEIN, 1998, p. 883).

36 " $[\ldots]$ If you try it, I'll sing a song of my own. And even if the audience finds this boring, there's still something pleasantly comic about it". 
We should note that this first song follows a choral participation indicated by the XOPOY mark. Aristophanes enriches this play with a good percentage of lyrical passages related to the plot. Apparently, it seems to compensate for the absence of the chorus in this part of the drama. The characters sing, going along with the music executed by the flutist who is invited to join the scene (891-892). It thus indicates that the choir members were still in the orchestra. And so, from line 893, the battle between the crone and the young girl starts with both presenting arguments on which they support and emphasize the advantages of their respective age groups:
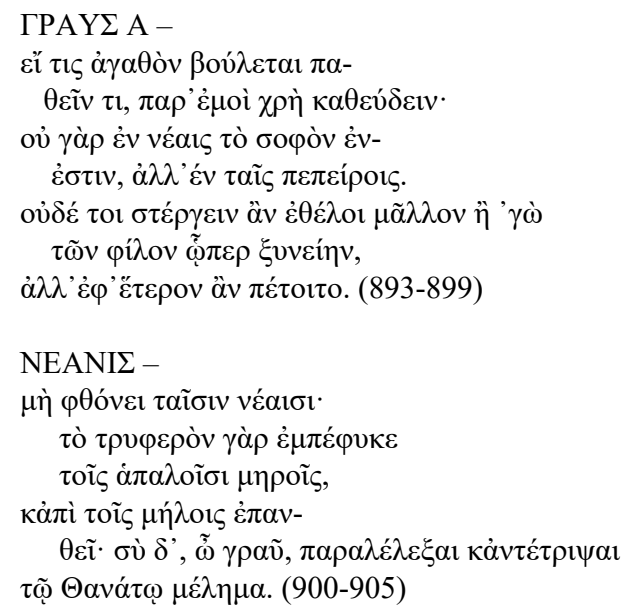

\section{FIRST OLD WOMAN -}

Whoever wants to have a good time should sleep with me.

For finesse dwells not in girls

But in ripe women.

You can bet she's no readier than I to cherish the boyfriend I'm with, but more likely to flit to another.

GIRL -

Don't despise the girls, for softness resides in their tender thighs and blossoms on their boobs.

But you, old bag, are tweezed and plastered, The Grim Reaper's heartthrob. ${ }^{37}$

The meter mainly used in that excerpt is the trochaic (-uu), probably chosen to indicate the ruffle in a scene and the thrill of excitement out of the quarrel. The scene shows the opposition between the contenders not only regarding the content but also the form.

37 A literal translation of this verse would be "You look like the darling of Death", showing that the crone actually prepares herself to meet Death (a male Greek word), thus drawing the picture of an ugly old lover. 
Thus, this first moment of the episode combines a whole image on stage: the crone who has on her disposal all the weapons in the art of seduction, including her own experience, and the young girl, who has nothing to offer but what nature grants her. On that account, the latter does not even need to draw upon resources such as excessive makeup or sexy clothing, for instance. The humor of this first part of the scene is caused by the accurate description of the old lady's visual features who tries to become more attractive but still has a repulsive look despite her best efforts.

The seductive weapons of the crone will be tested with the arrival of Epigenes, who sings when he first appears on the scene. He feels unfortunate for the duty of having sex with a crone instead of being able to get on with his beloved. For this sake, he calls on the fact of being a free man. The crone then answers to his lamentations and tries to seduce him and win the dispute with the young girl. The new law established by the Assembly gives her the guarantee of success on her attempt.

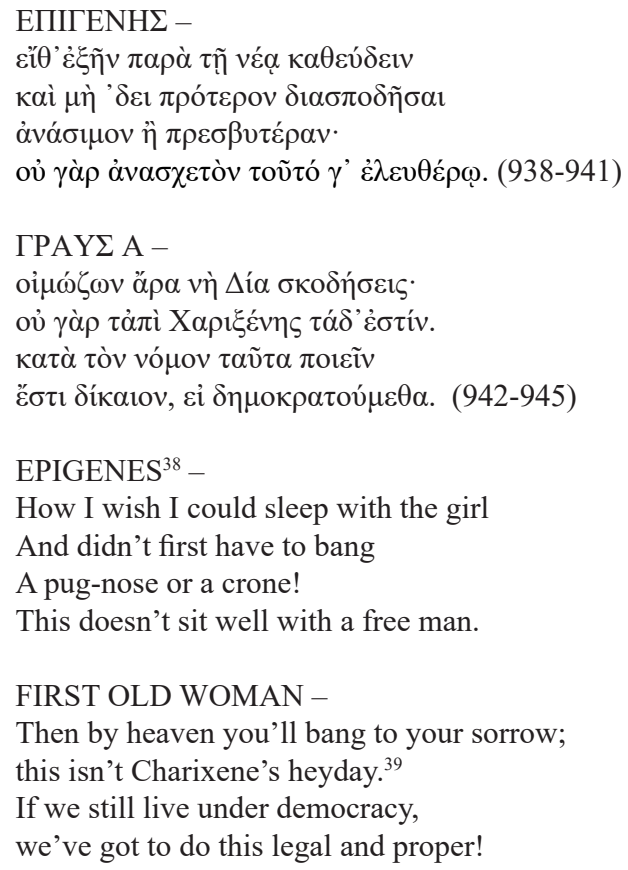

\section{Private affair versus politics}

Although they are still arguing about sex, a question of political nature is raised here, since now sex is guaranteed by law for everybody. The idea here is that young people cannot be left to couple with whomever they want, as in an environment of free love, referred

38 The word Epigenes can not necessarily be used as a proper name. Etymologically, the word means "born after", "young", indicating that the character is a young man.

39 "Evidently a courtesan of the pre-democratic era", observes Henderson (2002, p. 379). 
to in the Greek source text by the name of Charixenes (943), possibly a prostitute in previous times. Instead of choosing someone the young man likes, he must thus comply with what the new rule dictates: to satisfy the ugliest and oldest first.

The final word in this passage expressed by both young man and crone respectively makes a reference to the democratic state: $\dot{\varepsilon} \lambda \varepsilon v \theta \dot{\varepsilon} \rho \omega$ (941) and $\delta \eta \mu о \kappa \rho \alpha \tau o u ́ \mu \varepsilon \theta \alpha(945)$. He claims to be free, so he should not be forced to have sexual intercourse with someone he does not want to, while she, in keeping with the new law, states that both live in a democratic state, whose rules must be obeyed. So, the question remains: how to maintain freedom, the primordial concept of the idea of citizenship if there is law enforcement? How can freedom and obligation be reconciled?

Taking up the words of Aristotle in Politics (1317a40), "vं $\pi$ ó $\theta \varepsilon \sigma 1 \varsigma \mu \varepsilon \dot{\varepsilon} v$ oũv $\tau \tilde{\eta} \varsigma$

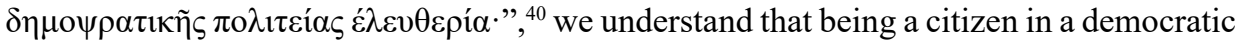
system means to be free. This freedom is a characteristic that distinguishes the citizen from the slave, since the former, taking possession of his life, can make of it whatever he wants, while the slaves' life and body belong to his master.

The philosopher laid stress that democratic freedom consists of an alternation of

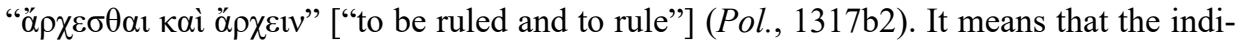
vidual must be actively involved in the government, and must also surrender to its power, letting himself be governed, and controlled. He has to obey orders that come from decisions taken by the majority (Pol., 1317b3-4). Aristotle reminds us that to be free implies to submit oneself to the laws since, in democracy, the people's decision is sovereign (Pol., 1317b10), considering that the Assembly ought to be the highest instance in the democratic government (Pol., 1317b29).

\section{A rebellion for love}

In the last episode of Assemblywomen we started to examine above, there is a showdown between Epigenes and the older women (938-1048), with a short participation of the young girl during this discussion (952-959b). ${ }^{41}$ The will of the chief Praxagora is represented by the female characters, who enforce what has been voted at the meeting in the Assembly, for the decree imposes on the young men the task of satisfying those who are ugly and old. However, the way how the old ladies execute the heroine's plan runs a bit out of control, reaching the realm of absurdity by having three crones quarreling over a young man, who wants to be with the young girl, as we can see below when the lovers sing to each other (952-968b):

\footnotetext{
NEANI $\Sigma$ -

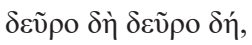

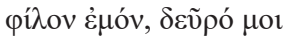

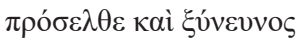

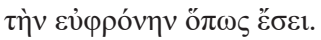

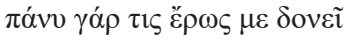

\footnotetext{
40 "Freedom is the foundation of the democratic constitution". All the translations of Aristotles's Politics were made by H. Rackham (1959).

41 Before this part, this last episode starts with a dispute between the girl and the old woman (877-937).
} 
$\tau \tilde{\omega} v \delta \varepsilon \tau \tilde{\omega} \nu \sigma \tilde{\omega} v \beta о \sigma \tau \rho v ́ \chi \omega \nu$.

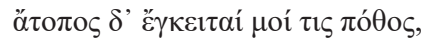

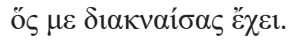

$\mu \varepsilon \dot{\theta \varepsilon \varsigma, ~ i \kappa v o u ̃ \mu \alpha i ́ ~ \sigma ' ~ ’ Е \rho \omega \varsigma, ~}$

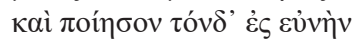

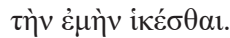

\section{ЕПІГЕNH -}

$\delta \varepsilon \tilde{\rho} \rho \circ \delta$ ঠे $\delta \varepsilon \tilde{u} \rho \circ \delta$,

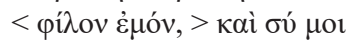

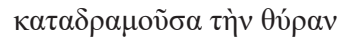

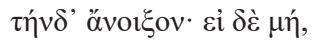

$\kappa \alpha \tau \alpha \pi \varepsilon \sigma \grave{v} \kappa \varepsilon i ́ \sigma o \mu \alpha$.

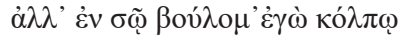

$\pi \lambda \eta \kappa \tau i ́ \zeta \varepsilon \sigma \theta \alpha 1 \mu \varepsilon \tau \alpha \grave{\alpha} \tau \tilde{\eta}_{\varsigma} \pi v \gamma \tilde{\eta} \varsigma$.

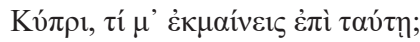

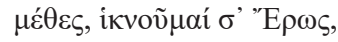

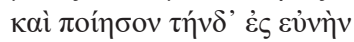

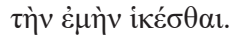

YOUNG GIRL -

Hither now, hither now,

my dear one, hither

come to me and promise to be

my bedmate through the night.

A powerful passion sets me awhirl

for those curly locks of yours.

A strange longing besets me

and grinds me in its grip.

Release me, Eros, I beg you!

Please make this boy

come to my very own bed.

\section{EPIGENES -}

Hither now, hither now, you too, my dear one,

run down to this door for me

and open it wide; if you don't,

I'll fall flat on the doorstep!

But I'd rather lie in your lap

And swap strokes with your butt.

Aphrodite, why drive me mad for this girl?

Release me, Eros, I beg you!

Please make this girl

Come to my very own bed.

There are still ongoing discussions whether this love duet is a $\pi \alpha \rho \alpha \kappa \lambda \alpha v \sigma i \theta v \rho o v$ (paraklausithyron), also known under the Latin term exclusus amator, that consists in a song chanted in a mournful voice by the excluded lover, which takes place on the doorstep of the unwilling beloved's house. Usually, it is only performed by a man. But here there is 
a woman singing together with him. It adds grace to the scene to show the role of swapping between genders. We can also think that Aristophanes is parodying a paraklausithyron. What happens in the scene is not only that the girl sings, but that she additionally takes the initiative and shows her desire for him to come into her house, instead of rejecting him. In the end, the male lover will intone the strophe and the following antistrophe without the participation of the girl (969-975), but what we could see on stage is a not-unwilling woman at the window. ${ }^{42}$ It makes a big difference in the features of this scene.

This first frame is interrupted by the return of the first crone in 976, which reminds the boy that he must first knock on her door. It triggers a heated discussion, which also includes the young girl who compares their relationship to Oedipus and Jocasta (1042).

Even though the crone reminds Epigenes that the new law (vó $\mu \circ \varsigma$ ) must be obeyed (1049-1051), so the young girl leaves the scene. At this moment, the crone will be chal-

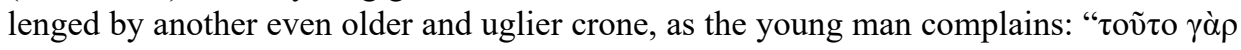

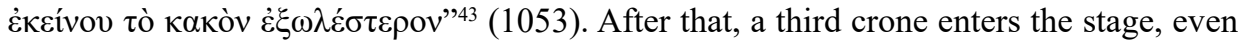
worse than the other two (1070). The poor guy is under pressure from the new obligation, and he ends the scene in agony, disputed by the crones for him to satisfy them.

\section{The tricks of a coup}

If we return to the beginning of the play, we see that Praxagora presents women like goods; they will be a common property of all (614-615). Then to distinguish them, initially, she does not oppose ugly to beautiful. However, she differentiates between the more neglected, poor or homely ( $(\alpha v \lambda$ ó $\tau \varepsilon \rho \alpha 1)$ and the nobles or "bob-nosed" ( $\sigma \mu \rho$ ó $\varepsilon \rho \alpha \imath)$, declaring the first ones ugly ( $\alpha i \sigma \chi \rho \alpha$ ) $(617-618) .{ }^{44}$ She actually proposes the elimination of social disparities that prevent free access to pleasure, as Saïd reflects (1996, p. 308), since the rich can be nicely dressed, becoming more attractive. This plan wants to mock and tease those who have a better economic condition as it aims to benefit ordinary people, as the neighbor concludes:

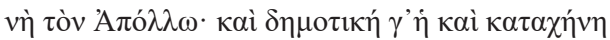

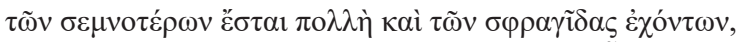

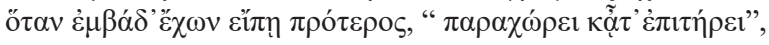

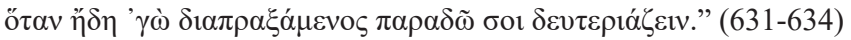

Absolutely. What's more, it's an idea that favors ordinary people, and it'll be a great joke on the big shots with signet rings when a guy wearing clogs speaks up and says, "Step aside and wait till I'm finished; then I'll give you seconds!"

Nevertheless, despite what is suggested in the above verses, the scene of the last episode of the play portrays women, the old ones, taking advantage of this new world, which initially seemed to favor older men, showing all the women as commodities, especially

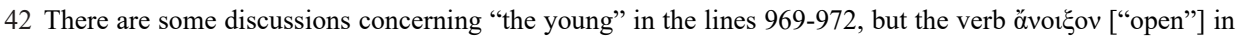
971 can only be used by the young man who wants to enter the house of his beloved.

43 "This horror is even more revolting than the last one!"

44 It is possible that this passage is an allusion to what a person with money can buy to be more attractive.
} 
the young ones, making Praxagora's proposal more interesting for men. We can understand that the heroine, as a leader, made a speech as a demagogue, showing the benefits of her plan to men only to convince them and get their support, behaving like them when in power by making promises that will never be fulfilled, if we consider that the example is given in the third episode (877-1111) to show women taking advantage of a man. We also have to consider that the women exploited the new rule to the extreme in the scene where they compete for the young man, because they neither let the first crone enjoy carnal pleasures with the young man nor do they care about the young man's complaints.

In the exodos, the only one who appears to be enjoying the new living conditions promised by the leader Praxagora is Blepyrus, her husband. The maid comes to the scene to take him to the dinner since he is late. She invites the judges, the spectators, telling i $\tau \omega$

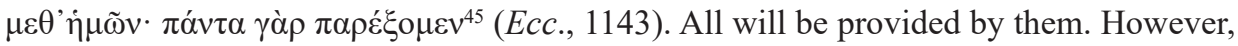
when it is Blepyrus turn, he is very clear:

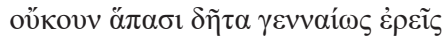

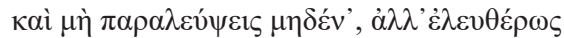

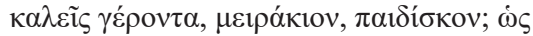

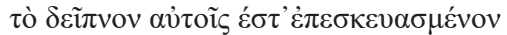

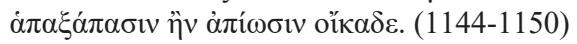

Why don't you be a lady and address all of them, leaving no one out? Be liberal, invite the old man, the boy the little child: there's dinner specially made for all of them - if they hurry home!

In this part of the play, Blepyrus cools down the expectation of having everyone participating in the dinner, after the city had become wealthy. He sends people home, showing that, in fact, the banquet is reserved for him, the two girls, his wife, and her friends. No one else is shown in this celebration, except the court of Praxagora. Does it mean that the collected properties will serve only a small part of the society and not the whole city, as promised? Can it be that all that was said by Praxagora and the Maid were vain words? Instead of inviting everybody to join them, as in Birds, Peace, and Wealth, what we see is an "uninvitation" - once promised, but not fulfilled. We could say that, once more, it is a big frustration: no redistributing, no dinner is played on stage. ${ }^{46}$

Here we can see the contradictions of the Athenian democracy that preserves the distance between different social groups at that time. We cannot forget that those who were predominantly speaking at the Assembly were trained and experienced orators. Although everyone had the right to speak, this space could be dominated by demagogues who helped to deepen the gap between rich and poor, manipulating the latter with lies and false promises. ${ }^{47}$

45 "Come along with us? We'll supply everything."

46 Only the dinner is addressed in the plot, when the maid tells that Blepyrus and the two girls are the last ones to arrive $(1133,1136)$. But we don't know who was there. The whole city? The Praxagora's entourage? Only the heroine's husband is shown in an advantageous situation with the 2 young girls and having access for the dinner.

47 Aristotle, Politics 1304b19-25. According to the philosopher, when demagogues wanted to take the goods of the rich, they instigated the poor against this group (see Politics, 1305a). 
Aristotle tells us how, in $411 \mathrm{BC}$, the people were deceived by the Council of the Four Hundred, ${ }^{48}$ when they said that the king of Persia would send more money to help the Athenians in the war against Sparta, thus receiving the support of the masses. He criticizes a democratic environment in which the citizens have such a leading role in the decision-making. He is accusing this fact to be the root cause of the existence of demagogues. ${ }^{49}$ When the farmer class and the class in possession of moderate property is sovereign over the government, they rule according to laws (Pol., 1292b20).

Could it be the same mentality represented in this play? Sharing the wealth of the citizens means to enable people to "better" contribute on the political issues of the city? Why the play shows the farmers murmuring in line 433 ? Based on this perspective, it seems that the main problem is the unfairness on economic status among the population. Nevertheless, we consider the women's action on this play a coup since the redistributing of goods is only a promise, and all that was collected remained on the Praxagora's court domains, apparently.

And more than this: the handover of the wealth happened by force, not by the change of the population's mindset, besides the "good intentions" of the winning party. And, as Magnelli (2017, p. 409) notes:

Without denying the rights of imagination, and firmly believing that many spectators would have enjoyed the ludicrous gags of this play, I still wonder whether they might have considered Praxagora a reliable leader for their imaginary Athens. Could they find attractive, even as pure fantasy, the idea of contributing their property to the common fund and sleeping with an old hag?

We agree with him, when he concludes that Aristophanes creates here a dystopian world, where nobody wants to live.

\section{Conclusions}

The criticism of democracy in that time is originated from the observation that this kind of government is always in danger of been weakened by dubious and misleading choices. The example discussed earlier concerning the monetary remuneration given to the citizens for participating in the Assembly clearly shows that the higher number of people attending the meetings is caused by personal interest in the money received what does not make the respect for the democratic ideal increase.

The last two episodes of the second part of this play show us the following picture: the

scenes are driven by secondary characters who face that strong resistance in the fulfillment of what was voted at the meeting. These scenes show the discrepancy between the

48 Athenian oligarchy that tried to remain in power in the year $411 \mathrm{BC}$.

49 In Politics (1295b25-30), Aristotle says that the ideal city is composed of citizens who are neither poor nor rich but live in a kind of middle-class status. Like this they will neither covet another's possessions nor do they have possessions to be coveted. For him, the gap between rich and poor causes greed and distances its citizens from a city of philia. Of course, we need to state in this context that this is the point of view of the philosopher which most probably represents the mindset of an aristocratic member of the society at that time. 
enactment of a decree and its implementation. Even enacted and aimed at the common good, when confronted with a conflict, personal interests impair or even disfigure the execution of the decision taken on the Assembly. But this resistance can still point out something else: the contradictions between what is promised by the politicians and what is delivered to the population.

When we come to the episode represented in 730-876, we can see that the so-called "selfish" character just wants to participate in those parts of the new order that will benefit him. He does not want to deliver his property but nonetheless wants to participate in the community dinner. The justification for such a behavior is very well formulated: he needs to see in order to believe because many laws that had been voted for the "good" of the people ended up favoring only one group, the demagogues. In fact, he states that citizens should take from the state without returning anything (779-783). He is considered greedy for not being proactively supporting a promised change that would benefit most citizens, especially the poor. However, he also represents someone who learned from the behavior of previous politicians. By his experience concerning the city's political background, he shows to be a critical thinker when confronted with something sold as "beneficial to all".

In the passage about the democratization of sex, the young man suffers from being forced to satisfy hideous horny crones. In this case, it sounds like criticism towards the implementation of decrees that are imposed without respect for the individual freedom of the citizens, just as the young man complains (938), especially in a sphere where only personal taste should prevail. On a greater scale the play exposes the danger of authoritarian tendencies in democratic regimes: the lack of respect for aspects of life that should be preserved in our free option and the imposition of the misplaced choices made by false promises and conducted through demagogues.

The plot of this play exposes that democracy requires from the citizens to be vigilant towards authoritarian tendencies, something that Dr. Otto Gritscheneder accurately formulated more than 2400 years later with the words "Wer in der Demokratie schläft, wacht in der Diktatur auf". 50

\section{References}

ANTIPHON; ANDOCIDES. Minor attic orators I. London: Harvard University Press, 1968. Available at:

http://www.perseus.tufts.edu/hopper/text?doc=Perseus\%3Atext\%3A1999.01.0018\%3As peech\%3D1\%3Asection\%3D87. Accessed: 26 jun. 2020.

ARISTOPHANES. Frogs. Assemblywomen. Wealth. Cambridge: Harvard University Press, 2002.

. Ecclesiazusae. Warminster: Aris \& Phillips LTD, 1998.

. Aristophanes Fabulae II: lysistrata, thesmophoriazusae, ranae, ecclesiazusae, plutus, fragmenta, index nominum. Oxford: Oxford University Press, 2007.

ARISTOTLE. La poétique. Paris: Seuil, 1980.

ARISTOTLE. $X X$ Aristotle: Athenian constitution, the Eudemian ethics, on virtues and vices. Cambridge: Harvard University Press, 1981.

50 "Who sleeps in a democracy wakes up in a dictature" (our translation). 
. Politics. Cambridge: Harvard University Press, 1959.

DEMOSTHENES. Against Timocrates. London: William Heinemann Ltd., 1956.

DOVER, Kenneth. Aristophanic comedy. California: The University of California Press, 1972.

DRUMOND, Greice. Lei e liberdade em “Assembleia de Mulheres” de Aristófanes. Caliope: Presença Clássica, Rio de Janeiro, n. 28, p. 10-31, 2014. Available at: https:// revistas.ufrj.br/index.php/caliope/article/view/7353/7123. Accessed: 29 jun. 2020. GRITSCHNEDER, Otto. Interviewed by Isabella Schmid for Das Online-Angebot des Bayerischen Rundfunks, 29 jun. 1999. Available at: https://www.br.de/fernsehen/ardalpha/sendungen/alpha-forum/otto-gritschneder-gespraech100 attachment.pdf?. Accessed: 25 apr. 2020.

HANSEN, Mogens H. Did the Athenian Ecclesia legislate after 403/2 BC.? In: Greek, Roman and Byzantine Studies, n. 20, p. 27-53, 1978. Available at: https://grbs.library. duke.edu/article/download/7261/4945. Accessed: 25 apr. 2020.

HAZEL, John. Who is who: in the Greek World. London: Routledge, 2002.

HENDERSON, Jeffrey. Text, notes and translation. In: ARISTOPHANES. Frogs. Assemblywomen. Wealth. Cambridge: Harvard University Press, 2002.

(ed.). Text, notes, translation. In: ARISTOPHANES. Fragments. Cambridge:

Harvard University Press, 2007.

KIBUUKA, Greice. A comédia de Aristófanes na fase de transição. 2010. PhD thesis, Faculdade de Letras, Universidade Federal do Rio de Janeiro: Rio de Janeiro, 2010. Available at: http://www.posclassicas.letras.ufrj.br/images/Cursos/Td/ teses/2010/201001-tese_GreiceFerreira.pdf. Accessed: 5 mar. 2020.

LEWIS, David M. Sparta as Victor. In: et al (eds.). The Cambridge Ancient History: the fourth century BC. Cambridge: Cambridge University Press, 1994.

MACDOWELL, Douglas M. Aristophanes and Athens. Oxford: Oxford University Press, 1995.

MAGNELLI, Enrico. Rethinking Aristophanes' comic hero: utopianism, ambiguity, and Athenian politics. Polis: the journal for Ancient Greek political thought, n. 34, 2017 , p. 390-404. Available at: https://brill.com/view/journals/agpt/34/2/article-p390_390. xml?language=en. Accessed: 5 mar. 2020.

MORRALL, John. Political thinkers: Aristotle. London: Routledge, 1977.

PLATO. The republic. Cambridge: Harvard University Press, 2013.

ROTHWELL JUNIOR, Kenneth S. Politics and persuasion in Aristophanes Ecclesiazusae. Leiden: Brill Academic Pub, 1990.

The continuity of the chorus in fourth-century Attic comedy. In: DOBROV,

Gregory W. (ed.). Beyond Aristophanes: transition and diversity in Greek Comedy. Atlanta: Scholars Press, 1995.

SAÏD, Suzanne. The “Assemblywomen": Women, Economy and Politics'. In: SEGAL, Erich (ed.). Oxford readings in Aristophanes. New York: Oxford University Press, 1996.

SOMMERSTEIN, Allan H. Aristophanes and the demon poverty. In: SEGAL, Erich (ed.). Oxford readings in Aristophanes. New York: Oxford University Press, 1996. Translation, notes and text. In: ARISTOPHANES. Ecclesiazusae. Warminster:

Aris \& Phillips LTD, 1998. 
XENOPHON. Xenophon IV: Memorabilia. Oeconomicus. Symposium. Apologia. Cambridge: Harvard University Press, 2013.

ZUMBRUNNEN, John. Aristophanic comedy and the challenge of democratic citizenship. Rochester: University of Rochester Press, 2012.

Recebido em: 08/06/2020; Aceito em: 29/06/2020. 